\title{
A REJEIÇÃO DE YAHWEH AO CULTO EM AMÓS: EXEGESE DE AMÓS 5,21-27*
}

\section{YAHWEH'S REJECTION OF THE AMOS CULT: EXEGESIS OF AMÓS 5:21-27}

\section{Resumo:}

Thiago Guimarães Vicente ${ }^{1}$

O livro do profeta Amós é uma denúncia profética contra a prática opressora que os reinos de Israel e Judá praticavam contra o seu próprio povo. Em meio à prática abusiva, nem o culto a Yahweh ${ }^{2}$ se salva das duras palavras do profeta, afinal Amós é profeta de verdade! Em Amós 5,21-27, o profeta denuncia a rejeição de Yahweh ao culto e revela aos ouvintes a salvação pessoal, e não social, que pode ser encontrada na prática cúltica, através da humilhação e purificação no exílio que está por vir. Para tal resultado, fizemos uma exegese da perícope de Amós 5,21-27 da Bíblia Hebraica Stuttegartensia, junto a uma revisão de literatura, que abrangeram o contexto histórico do texto junto ao livro, à delimitação e à estruturação da perícope, que dão embasamento para o comentário exegético e para as considerações finais.

Palavras-chave: Amós; exegese; culto; rejeição; salvação.

\begin{abstract}
:
The book of the prophet Amos is a prophetic denunciation against the oppressive practice of the kingdoms of Israel and Judah against their people. During the abusive practice, not even the worship of Yahweh is saved from the harsh words of the prophet; after all, Amos is a true prophet. In Amos 5:21-27, the prophet denounces Yahweh's rejection of worship and reveals to his listeners the personal, and not social, salvation, that can be found in cultic practice, through humiliation and purification in the coming exile. To this end, we exegeted the perícope of Amos 5:21-27 of the Hebrew Bible Stuttegartensia with a literature review, which covered the historical context of the text concurrently with the book, the delimitation, and structuring of the perícope, which provide the basis for the exegetical commentary and the final considerations.
\end{abstract}

Keywords: Amos, exegesis, worship, rejection, salvation.

\section{Introdução}

O presente artigo é uma exegese da perícope de Amós 5,21-27. O cânon hebraico é chamado pelos judeus atualmente de "Tenak" e é formado por três partes: a Lei (Tora), os Profetas (Nebiim) e os Escritos (Ketubim). O livro de Amós está incluído na segunda parte chamada de: "Os Profetas"; dentro da segunda subparte da mesma, chamada de: "Os Profetas Posteriores". A

* O presente trabalho foi realizado com apoio do CNPq, Conselho Nacional de Desenvolvimento Científico e Tecnológico - Brasil. Enviado em: 28.02.2019. Aceito em: 06.05.2020.

1 Graduado em Teologia. Mestrando em Ciências da Religião. E-mail: thigv@icloud.com.

2 Todas as citações para o tetragrama hebraico do nome de Deus, transliterado por: YHWH, no atual artigo transliteramos por "Yahweh".

Protestantismo em Revista | São Leopoldo | v. 45, n. 02 | p. 49-63| Jul./dez. 2019 
subparte conhecida como "Os Profetas Posteriores" é formada pelos livros: Isaías, Jeremias, Ezequiel e o livro dos Doze Profetas. O livro dos Doze Profetas é o conjunto de doze livros proféticos de Oseias a Malaquias. Na Bíblia Cristã, o Antigo Testamento segue a divisão da Septuaginta, e o livro de Amós faz parte dos chamados Livros Proféticos, dentro da subparte chamada: "o Livro dos Doze Profetas Menores"3.

Os livros proféticos são conhecidos principalmente por serem uma proclamação oral que posteriormente fora escrita. Os profetas são conhecidos não por serem aqueles que escreveram, mas por serem aqueles que o falaram, como mensageiros, em nome de Yahweh ${ }^{4}$. Como afirma Schmidt": "A situação original em que atuavam era a de proclamação oral no contato direto com o ouvinte". No caso do livro de Amós, toda a compreensão de Amós é mediada por um texto, mais especificamente pelo seu livro, porque as únicas informações que temos sobre o profeta encontram-se no livro que leva o seu nome. Dessa forma, entendemos "as palavras de Amós" (Am 1,1) como literatura, e o livro de Amós como um agrupamento de ditos proféticos. ${ }^{6}$

Portanto, justificamos a necessidade da exegese da perícope de Am 5,21-27, que está inserida no livro para uma melhor compreensão, mas que não deixa de olhar para o contexto no qual está inserida para que essa compreensão se dê de forma clara e concisa. A relevância do livro de Amós é demonstrada por autores como Schwantes ${ }^{7}$, que considera Amós como um profeta de verdade, pois a terra não pode suportar as suas palavras, palavras que o profeta usa para denunciar a prática opressora dos reinos de Israel e Judá para com seu próprio povo. Para o autor, parece que não existe salvação no discurso de Amós. E no meio de toda a denúncia da prática abusiva, nem o culto a Yahweh se salva. E justamente a perícope em questão, de Am 5,21-27, vai nos revelar a denúncia do profeta quanto à rejeição de Yahweh ao culto. Talvez este seja o cerne de todo o livro, o ápice da impiedade e da injustiça, que são demonstradas por duras palavras do profeta, de que Yahweh não está presente nessa sociedade opressora, nem em seus cultos; e dessa forma também revele aos ouvintes uma salvação que poderá ser encontrada no caminho da conversão da prática diária, em observância ao direito e à justiça de Yahweh, que só poderão ser alcançadas em meio ao castigo da impiedade.

Assim, nesse artigo fizemos a exegese da perícope de Amós 5,21-27, demonstrando os pormenores da rejeição de Yahweh ao culto de seu povo, e como o profeta revela o caminho da salvação. Para isso, apresentamos uma exegese que será subdivida em itens: uma pequena introdução ao contexto histórico do tempo no qual o profeta Amós profetizou; uma tradução literal interlinear hebraico-português; uma tradução literal em português; uma delimitação e estrutura da perícope em questão; o comentário exegético da perícope de acordo com a estruturação proposta anteriormente, dividida em subpartes; e por fim, as considerações finais.

* Mestrando em Ciências da Religião. Universidade Metodista de São Paulo. E-mail: thigv@icloud.com

3 RENDTORFF, Rolf. Antigo Testamento: uma introdução. Tradução de Monika Ottermann. Santo André, SP: Academia Cristã, 2009. p. 242, 272-273, 345. SCHMIDT, Werner H. Introdução ao Antigo Testamento. Tradução de Annemarie Hõhn I. 3a Edição. São Leopoldo, RS: Sinodal, 2004, p. 13, 16.

4 SCHMIDT, 2004, p. 168.

5 SCHMIDT, 2004, p. 168.

6 SCHWANTES, Milton. A terra não pode suportar suas palavras: reflexão e estudo sobre Amós. São Paulo: Paulinas, 2004, p. 137-159.

7 Por toda obra de Schwantes (2004), relevada pelo título da mesma, o autor considera que o papel principal do profeta é a denúncia contra a prática opressora, por tal o profeta Amós é considerado um profeta de verdade, que não usa meias palavras. SCHWANTES, 2004.

Protestantismo em Revista | São Leopoldo | v. 45, n. 02 | p. 49-63| Jul./dez. 2019

Disponível em: <http://periodicos.est.edu.br/index.php/nepp> 


\section{Contexto Histórico}

Iniciamos a exegese da perícope, primeiramente com o entendimento do contexto que a mesma está inserida, o livro de Amós, e a atuação do profeta Amós quando os ditos proféticos aconteceram. A atuação profética de Amós é datada na segunda metade do século $\mathrm{VIII}^{8}$, em torno do ano 760 a.C., no reinado do rei de Israel, Jeroboão II, e do Rei de Judá, Uzias ${ }^{9}$, no período mais próspero de ambos os reinos, do Norte e do Sul ${ }^{10}$.

O reinado de Jeroboão fora longo, algo em torno de 41 anos, de 793 a 753 a.C. ${ }^{11}$, e Israel tinha um poderio mais forte contra seus vizinhos nesta época, fazendo o mais extenso e mais bemsucedido governo de Israel ${ }^{12}$, principalmente devido ao enfraquecimento da Assíria ${ }^{13}$. Isso levou Israel à ampliação de suas fronteiras no Norte e no Sul para, em especial, alcançar as rotas comerciais e ter o seu controle, e assim, a sua tributação ${ }^{14}$. Afinal, Israel ocupava um lugar privilegiado no sistema de rotas comerciais. Isso fortaleceu a agricultura e o poderio militar.

O reino do Sul, Judá, também perdurou um longo período no governo de Uzias, aproximadamente de 790 a.C. a 740 a.C., cerca de 52 anos $^{15}$. Ambos os monarcas, do Norte e do Sul, eram expansionistas e consolidadores ${ }^{16}$, e ambos desfrutaram de um período de paz até que Tiglate-Pileser III, subisse ao trono da Assíria em 747 a.C.; mas, por enquanto, há paz para Israel em torno de 760 a.C., época em que a mensagem de Amós deve ter sido anunciada ${ }^{17}$.

O pano de fundo do profeta Amós é um Estado próspero em expansão territorial e poderio militar, um Estado seguro. No entanto, como Amós é conhecido como "profeta da justiça", boa parte do anúncio profético é contra a riqueza de ambos os Reinos, Norte e Sul, principalmente contra Israel, que denuncia uma riqueza oriunda de todas as formas de injustiça social, e por isso lança de anátemas contra aqueles que deveriam propagar a justiça, o próprio povo de Deus ${ }^{18}$. A fé para Amós deve ser traduzida em justiça social, que brota de uma relação perfeita com Deus ${ }^{19}$. Por isso também anuncia a rejeição ao culto por parte de Yahweh, causada, não por um desvio de ritual prescrito, mas por sua junção: o holocausto e a injustiça, a oração e a opressão, o rito e a alienação humana; pois não basta um culto intimista e limitado à consciência, mas um culto ligado à realidade social humana (o que veremos em pormenores no comentário exegético) ${ }^{20}$.

Na continuação, faremos a tradução literal da perícope em questão, primeiramente com o texto interlinear hebraico-português, e posteriormente, para melhor leitura do texto, a tradução literal apenas em português.

REIMER, Haroldo. A Festa dos Pândegos Sobre o comer e beber no livro de Amós. Estudos Teológicos, v. 49, n. 2, p. 344-355, São Leopoldo, jul./dez. 2009, p.345.

9 SCHWANTES, Milton. Amós: Meditações e estudos. Sinodal: São Leopoldo, 1987, p.12.

10 LOPES, Hernandes Dias. Amós: um clamor pela justiça social. São Paulo: Hagnos, 2008, p.17.

11 LOPES, 2008, p.17.

2 LOPES, 2008, p.17.

LOPES, 2008, p.17.

SCHWANTES, 1987, p.13. REIMER, 2009, p.345. SCHWANTES, 2004, p.12.

LOPES, 2008, p.17-18.

LOPES, 2008, p.18

KIRST, Nelson. Amós: textos selecionados. São Leopoldo: Faculdade de Teologia, 3 Vol., Exegese, 1. 1981, p.13-14.

BONORA, Antônio. Amós, o profeta da justiça. Tradução de Pier Luigi Cabra. 2. ed. São Paulo: Paulinas, 1988, p.23.

KIRST, 1981, p.13-14.

KIRST, 1981, p.13-14.

Protestantismo em Revista | São Leopoldo | v. 45, n. 02 | p. 49-63| Jul./dez. 2019

Disponível em: <http://periodicos.est.edu.br/index.php/nepp> 
Tradução Literal Interlinear (Am 5,21-27) ${ }^{21}$

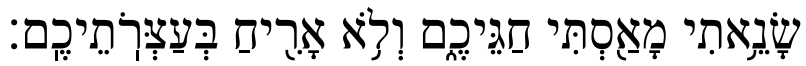

(Eu) odeio, (eu) rejeito as vossas festas sacrificiais e (eu) não cheiro/aceito as vossas reuniões festivas/cúlticas.

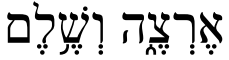

Porque, mesmo que me ofereçam os sacrifícios queimados e as vossas ofertas de cereais, não as aceitarei; e a oferta pacífica de vossos animais cevados não contemplarei/aceitarei.

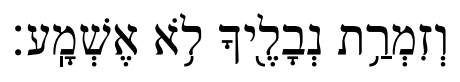
escutarei.

Afasta de junto de mim a multidão das tuas canções; e o som das tuas harpas não

E que o direito flua como as águas; e a justiça como manancial corrente.

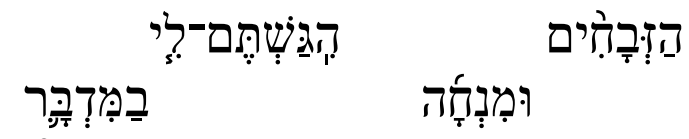

Por acaso sacrifícios e ofertas de cereais oferecestes-me no deserto, durante quarenta anos, ó casa de Israel?

6

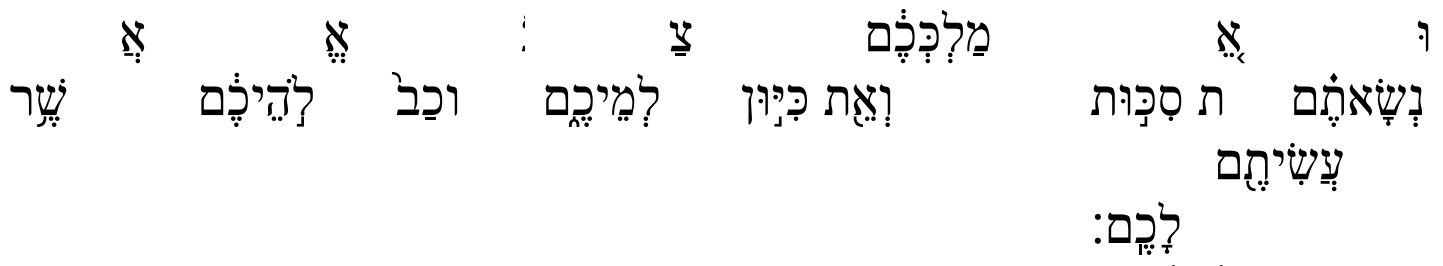

E carregastes Sicut, o vosso rei, e Quium, as vossas imagens; a estrela dos vossos deuses fundiram/fizestes para vós.

פ :

7 nome.

Tradução Literal ${ }^{22}$

21 Apresentamos uma versão própria tanto na "Tradução interlinear literal" quanto na "Tradução literal" do Texto de Am 5,21-27 da Bíblia Hebraica Stuttegartensia (2003). Procuramos manter a ordem frasal e o sentido literal dos vocábulos, introduzindo poucas alterações, apenas para facilitar a leitura em língua portuguesa. As palavras que se encontrarem entre parênteses não tem um similar em hebraico mas forma inseridas para mostrar ênfase e para facilitar a leitura em língua portuguesa. As palavras que estão acompanhadas de ' $/$ ' são duas possíveis traduções para as palavras. WEIL, G. E., ELLIGER, K., \& RUDOLPH, W. Biblia Hebraica Stuttgartensia, SESB version, electronic ed., Stuttgart: German Bible Society, 2003.

22 Apresentamos uma versão própria tanto na "Tradução interlinear literal" quanto na "Tradução literal" do Texto de Am 5.21-27 da Bíblia Hebraica Stuttegartensia (2003). Procuramos manter a ordem frasal e o sentido literal dos vocábulos, introduzindo poucas alterações, apenas para facilitar a leitura em língua portuguesa. As palavras que se encontrarem entre parênteses não tem um similar em hebraico mas forma inseridas para mostrar ênfase e para facilitar a leitura em língua portuguesa. As palavras que estão acompanhadas de ' $/$ ' são duas possíveis traduções para as palavras. WEIL et al, 2003.

Protestantismo em Revista | São Leopoldo | v. 45, n. 02 | p. 49-63| Jul./dez. 2019 
21 (Eu) odeio, (eu) rejeito as vossas festas sacrificiais e (eu) não cheiro/aceito as vossas reuniões festivas/cúlticas.

22 Porque, mesmo que me ofereçam os sacrifícios queimados e as vossas ofertas de cereais, não as aceitarei; e a oferta pacífica de vossos animais cevados não contemplarei/aceitarei.

23 Afasta de junto de mim a multidão das tuas canções; e o som das tuas harpas não escutarei.

24 E que o direito flua como as águas; e a justiça como manancial corrente.

25 Por acaso sacrifícios e ofertas de cereais oferecestes-me no deserto, durante quarenta anos, ó casa de Israel?

26 E carregastes Sicut, o vosso rei, e Quium, as vossas imagens; a estrela dos vossos deuses fundiram/fizestes para vós.

27 (Eu) vos exilarei para além de Damasco, disse Yahweh, Deus dos Exércitos é o seu nome.

\section{Estrutura e delimitação: Revisão de literatura}

Para uma exegese pertinente, clara e concisa, entendemos que, após a tradução literal, temos que fazer a estruturação e delimitação da perícope. E assim o faremos, após uma breve revisão de literatura. Na revisão, observamos que a estruturação, ou mesmo que a própria perícope de Am 5,21-27, é muitas vezes ignorada pelos exegetas ou mesmo comentada esporadicamente em suas obras, como em Schwantes ${ }^{23}$ e Wolff ${ }^{24}$. Somado a isso, encontramos uma dificuldade de clareza entre autores quanto à delimitação, subdivisão e exegese.

Dessa forma, para os autores: Crabtree ${ }^{25}$, Bonora ${ }^{26}$ e Wolff ${ }^{27}$, Am 5.21-27 integra uma perícope por completo. Além disso, esses autores a estruturam cada um à sua maneira. Crabtree ${ }^{28}$, divide-a em duas partes: "O Senhor rejeita sacrifícios e exige justiça", 21 a 25 e 26 a 27 e "O Exílio de Israel é inevitável". Bonora ${ }^{29}$, com o título do capítulo: "A droga do culto formalístico", subdividea em quatro partes: "1. Crítica à liturgia", Am 5,21-23; "2. 0 ideal do deserto (releitura deuteronomista)", Am 5,25-27; "3. Liturgia e justiça", Am 5,24; "4. Salvação bloqueada". E Wolff ${ }^{30}$, chama Am 5.21-27 de "A rejeição da Adoração".

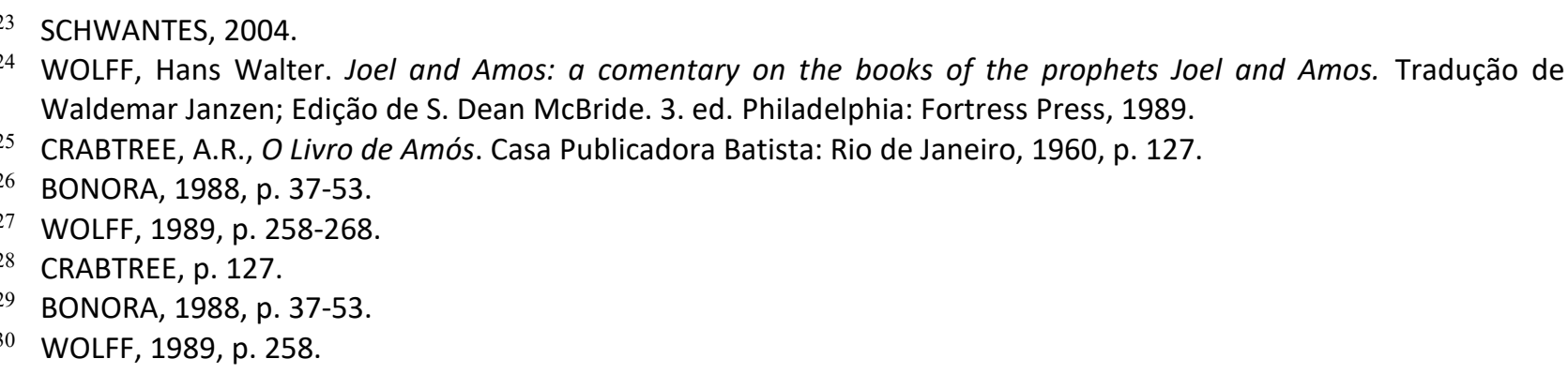

Protestantismo em Revista | São Leopoldo | v. 45, n. 02 | p. 49-63| Jul./dez. 2019 
Enquanto para outros autores como: Lopes ${ }^{31}$, Brown et $a l^{32}$, Smith ${ }^{33}$, Alonso Schökel e Sicre Diaz $^{34}$, e Hubbard ${ }^{35}$ Am 5.21-27 é ampliada, sendo composta por mais versículos. Lopes $^{36}$ estende a perícope para 5.14-27 no sétimo capítulo chamado: "Quando a religião perde o seu poder" subdividindo-a em três partes: 1. "Estará Deus conosco mesmo em Berseba?", Am 5,14-20; 2. "As implicações de estar com Deus e andar com Ele", Am 5.14-15; 3. "Gilgal, herança ou exílio?" 5.2127. Para Brown et $a l^{37}$, a delimitação é de 5,18-6,14, intitulado: "Três Avisos", subdividido em seis partes, sendo a segunda parte Am 5.21-27, chamada de "A adoração corrompida de Israel". E subdivide o texto em duas seções, Am 5,21-24 e Am 5,25-27, sendo uma linha comum entre ambas o tema dos sacrifícios, mas não nomeando cada subparte. Já para Alonso Schökel e Sicre Diaz ${ }^{38}$, a perícope é ampliada, 5,18 a 5,27, e intitulada: "Segundo Ai: culto e justiça", subdividindo-se em 5,1820 e 5,21-27. E por fim, para Hubbard ${ }^{39}$, a perícope integral engloba Am 5,18-27, chamada de "Oráculo do lamento: interpretação distorcida do dia de Javé", subdividida em três partes: 5,18-20: "Descrição do Dia de Javé"; 5,21-24: "Denúncia contra as celebrações na adoração pública"; e 5,2527: "Anúncio de juízo por meio do exílio".

\section{Estrutura e delimitação: considerações}

Diante das informações que foram observadas na breve revisão de literatura, e no texto da Bíblia Hebraica Stuttgartensia ${ }^{40}$ ao fazer a tradução do hebraico para o português, iremos, a seguir, delimitar e estruturar a perícope. Primeiramente, na análise exegética que fizemos dos autores e do texto hebraico, consideramos Am 5,21-27 uma perícope completa, mesmo que não haja um consenso entre todos os exegetas. Para Wolff" ${ }^{41}$ Am 5,21-27 "é estilisticamente diferenciada da unidade precedente $(5,18-20)$ pela mudança para a fala divina de primeira pessoa, que é mantida ao longo" dessa perícope.

E após essa delimitação, consideramos que Am 5,21-27 apresenta três subunidades:

1. A rejeição de Yahweh ao culto, Am 5,21-23;

2. A salvação de Yahweh para o culto, Am 5,24;

3. O caminho de Yahweh para a salvação do culto, Am 5,25-27.

31 LOPES, 2008, p. 125-139.

32 BROWN, Raymond E.; FITZMYER, Joseph A.; MURPHY, Roland E. Novo Comentário Bíblico São Jerônimo: Antigo Testamento. Trad. Celso Eronides Fernandes. São Paulo: Ed. Academia Cristã Ltda; Paulus, 2007, p.445-446.

33 SMITH, G. V. Amós. Tradutores S. Klassen \& V. da S. Santos, 1a edição, São Paulo, SP; Cambuci, SP: Editora Cultura Cristã, 2008, p.256-266.

34 ALONSO SCHÖKEL, L., \& SICRE DIAZ, J.L. Profetas II: Introducciones y comentario: Ezequiel, Doce Profetas Menores, Daniel, Baruc, Carta de Jeremias. Com a colaboração de S. Breton e E. Zurro, Cristianad: Madrid, 1980, p.979-980. Disponível em <https://pt.scribd.com/document/340608932/Profetas-2-Luis-Alonso-Schokel>. Acessado em 2 de outubro de 2018.

35 HUBBARD, David Allan. Joel e Amós: introdução e comentário. Tradução de Marcio L. Redondo. São Paulo: Edições Vida Nova, 2008, p.200.

36 LOPES, 2008, p. 125-139.

37 BROWN et al, 2007, p. 445-447.

38 ALONSO SCHÖKEL \& SICRE DIAZ, 1980, p. 979-980.

39 HUBBARD, 2008, p. 200-211.

40 WEIL et al, 2003.

41 WOLFF, 1989, p. 260.

Protestantismo em Revista | São Leopoldo | v. 45, n. 02 | p. 49-63| Jul./dez. 2019

Disponível em: <http://periodicos.est.edu.br/index.php/nepp> 
Veremos a justificação de tal divisão, nos parágrafos a seguir.

Na primeira parte, em 21-23, temos a apresentação do momento cúltico de Israel: festas, reuniões, sacrifícios, ofertas e música; e a sua rejeição por parte de Deus. Como enfatiza Alonso Schökel e Sicre $\operatorname{Diaz}^{42}$, um dos grandes temas do Antigo Testamento é a relação e a tensão entre o culto e a justiça social - como é visto repetidas vezes na literatura profética (Os 6,6; 1,10; Jr 7; Is 58, Zc 7), na literatura sapiencial ( $P \vee 15,8 ; 21,3$ ) e até em forma de oração (SI 50). Para o israelita, em primeiro lugar, o culto é uma prática para honrar ao $\mathrm{SENHOR}^{43}$, em segundo lugar, é uma prática que assegura o favor de Deus. No entanto, como os israelitas praticavam a injustiça que os enriquecia, por não desejarem mudar a sua conduta diária, e assim empobrecerem, usavam o culto como um suborno, comprando aparentemente o favor de Deus; o que acabaria se tornando algo viciante, pois quanto mais injustiça há, mais culto é necessário ${ }^{44}$.

Na segunda parte, no v.24, temos uma quebra no texto que sai do momento cúltico para a vida por completo, para a vida diária. Yahweh "convida" os ouvintes para que pratiquem o direito e a justiça continuamente, porque o verbo no hebraico g galal ("fluir"), traduzido por 'flua' (nossa tradução), 'corra' (interlinear hebraico-português) ${ }^{45}$ e 'revolva' (Bíblia de Jerusalém) ${ }^{46}$, está no nifal imperfeito jussivo da terceira pessoa masculina do singular ${ }^{47}$. 0 jussivo é geralmente usado na terceira pessoa para indicar a volição, o modo volitivo, isto é, a expressão de uma vontade. Aqui não é usado o imperativo como uma ordem absoluta, mas o jussivo, que expressa o desejo de uma vontade revelada por: uma ordem, um mandamento, um desejo ou um pedido ${ }^{48}$. Yahweh revela como Ele aceitará o culto, uma salvação que parece não existir no campo sistemático religioso oficial daquela comunidade perdida, mas que poderá ocorrer para o indivíduo que aceitar o convite.

E por fim, a terceira parte, v. 25-27, que para a maioria dos exegetas como: Brown et $a l^{49}$, Alonso Schökel e Sicre Diaz ${ }^{50}$, Wolff ${ }^{51}$ e o aparato crítico da Bíblia Hebraica Stuttgartensia ${ }^{52}$, podem indicar uma adição tardia, enquanto que para $S_{m i t h}{ }^{33}$ e Alonso Schökel e Sicre Diaz ${ }^{54}$, há uma difícil interpretação da explicação conclusiva sobre o significado desses versículos. No entanto, Bonora ${ }^{55}$ diz que parece ser uma releitura deuteronomista e que por essa razão indique o caminho da salvação para o povo através da releitura do deserto. Muito embora o v. 27, o último do capítulo 5 e da perícope, indique que talvez seja uma adição posterior, por falar do exílio, como também volta

42 ALONSO SCHÖKEL \& SICRE DIAZ, 1980, p. 980.

43 Todas as citações da palavra "Senhor" em caixa alta: "SENHOR" são a tradução para o tetragrama hebraico do nome de Deus: "YHWH", que no atual artigo transliteramos por "Yahweh".

44 ALONSO SCHÖKEL \& SICRE DIAZ, 1980, p. 980.

45 FRANCISCO, Edson de Faria. Profetas Posteriores: Antigo Testamento Interlinear Hebraico Português. Volume 3. Sociedade Bíblica do Brasil: Barueri, SP, 2017. 596-597.

46 A BíBlIA SAGRADA. A Bíblia de Jerusalém. Nova Edição Revista e Ampliada. 7a Impressão, edição de 1998, Editora Paulus: São Paulo, SP, 2011. Amós 5.21-27, p. 1621.

47 WOLFF, 1989, p. 260.

48 ROSS, Allen P. Gramática do Hebraico Bíblico. Tradução Gordon Chown, 2 ed., Vida: São Paulo, 2008, p. $154-156$.

49 BROWN et al, 2007, p.446.

50 ALONSO SCHÖKEL \& SICRE DIAZ, 1980, p. 980.

51 WOLFF, 1989, p.258.

52 WEIL, G. E., ELLIGER, K., \& RUDOLPH, W, Deutsche Bibelgesellschaft. Biblia Hebraica Stuttgartensia, 5. Aufl., rev., Stuttgart: Deutsche Bibelgesellschaft, 1997, p.1023.

53 SMITH, 2008, p.272.

54 ALONSO SCHÖKEL \& SICRE DIAZ, 1980, p. 979-980.

55 BONORA, 1988, p. 42-44.

Protestantismo em Revista | São Leopoldo | v. 45, n. 02 | p. 49-63| Jul./dez. 2019

Disponível em: <http://periodicos.est.edu.br/index.php/nepp> 
para a característica de Amós, de um verdadeiro profeta, do anúncio do castigo sem menção alguma de salvação no mesmo versículo para aquele sistema operante ${ }^{56}$.

Passaremos a seguir, para o Comentário Exegético, depois que fizermos: a introdução, contexto histórico, a tradução literal interlinear hebraico-português, a tradução literal, estrutura e delimitação: revisão de literatura, estrutura e delimitação: considerações. Agora, comentando os resultados da pesquisa exegética do texto da Bíblia Hebraica Stuttgartensia e da revisão de literatura, usando de três subitens, conforme apresentado na estruturação, para, por fim, termos nossas considerações finais.

\section{Comentário exegético}

A rejeição de Yahweh ao culto, Am 5,21-23

21

22

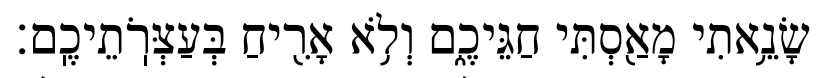

2

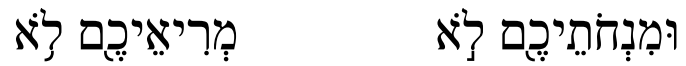

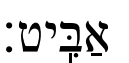

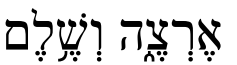

עוֹלוֹת

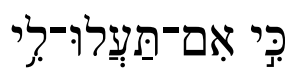

23

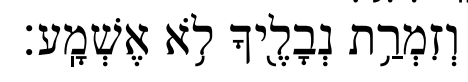

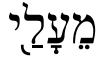

דֵָּסר

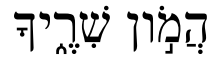

21 (Eu) odeio, (eu) rejeito as vossas festas sacrificiais e (eu) não cheiro/aceito as vossas reuniões festivas (cúlticas).

22 Porque, mesmo que me ofereçam os sacrifícios queimados e as vossas ofertas de cereais, não as aceitarei; e a oferta pacífica de vossos animais cevados não contemplarei/aceitarei.

23 Afasta de junto de mim a multidão das tuas canções; e o som das tuas harpas não escutarei.

O SENHOR é aquele que fala mediante a representação do profeta neste versículo, afirmando que Ele rejeita as práticas cúlticas de Israel ${ }^{57}$. Isso, porque o culto havia se tornado uma prática formal e externa, sem ligação com a vida diária dos israelitas ${ }^{58}$. "A vida precede o culto. Primeiro Deus aceita a nossa vida, depois Ele aceita o nosso culto" ${ }^{59}$. Uma prática do culto divorciada do amor de Deus e do amor ao próximo ${ }^{60}$ não pode ser aceita por Deus. A reunião festiva do culto

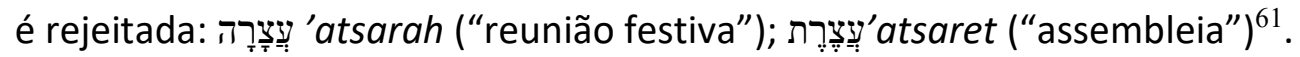

Amós denuncia que o povo de Israel ia ao templo de Gilgal, Betel e Berseba $(A m 5,5)$ para demonstrar uma religiosidade fabulosa: festivais, sacrifícios, ofertas e música em abundância ${ }^{62}$. Os israelitas eram observados cuidadosamente pelo profeta que via seus ritos religiosos (v.21), rituais fazendo de conta que tudo estava na perfeita ordem entre Deus e os outros do povo (v.22), sendo um culto alegre e cheio de entusiasmo, com muita música e celebração (v.23) ${ }^{63}$. Mas tudo isso não passava de sacrifícios e ofertas que Deus odiava e rejeitava (v.21), não aceitava e não contemplava

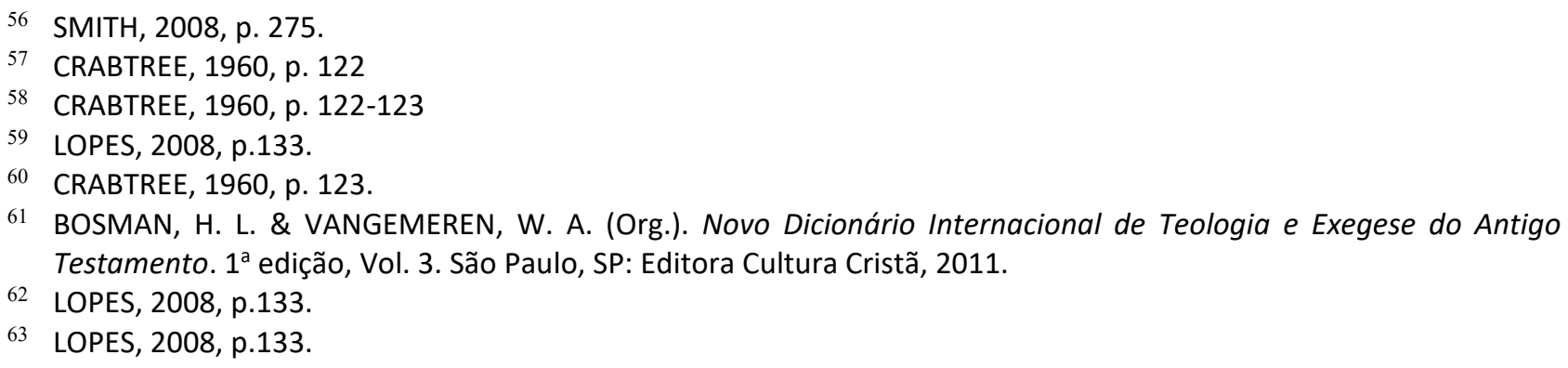

Protestantismo em Revista | São Leopoldo | v. 45, n. 02 | p. 49-63| Jul./dez. 2019 
(v.22), músicas que o SENHOR não queria ouvir nem de longe e que não escutava (v.23). Tudo porque os israelitas oprimiam o seu próximo, principalmente o mais pobre (Am 5,11), tratavam o tsaddiyq ("justo") com injustiça, praticavam o suborno (Am 5,7.12), e praticavam o mal continuamente na sua prática diária (Am 5,14-15). Os pobres, como demonstra Schwantes ${ }^{64}$, não são: mendigos, escravos, órfãos ou viúvas. Eles são, na verdade, homens livres que foram empobrecidos e se tornaram: pobres, magros, oprimidos, fracos e doentes. São a gente lavradora empobrecida que foi esmagada pelo sistema que tirou cada vez mais deles e deixou os ricos cada vez mais ricos. A prática da retirada extorsiva da produção camponesa, denominada de tributarismo, era uma política praticada no estado de Israel, que usurpava dos direitos humanos trazendo pobreza ao povo campesino ${ }^{65}$.

Durante a semana, o tsaddiyq ("justo"), que era: o pobre, o magro, o fraco, era oprimido pelos ricos e poderosos opressores, e no dia do culto, também era excluído pelos mesmos que o oprimia durante a semana. E para os opressores, depois do culto, parecia que tudo estava bem entre eles e Yahweh, entre eles e o próximo. Pelo que se evidencia, o pobre, justo, não participava do culto, pois as ofertas eram de "animais cevados" (v.22) e não as ofertas dos pobres de dois pombinhos ou duas rolinhas (Lv 12,8). Os ricos, poderosos e o exército adoravam a Deus com as reuniões festivas, segmentadas e exclusivistas, que Deus odiava e rejeitava, com reforço na tradução do "eu" enfático.

Além disso, Deus também afirmava que as suas reuniões festivas/cúlticas 'não me dão nenhum prazer', segundo Almeida Revista e Corrigida ${ }^{66}$, ou que 'não gostava', segundo a Bíblia de Jerusalém ${ }^{67}$. As traduções apresentadas vêm da palavra hebraica ำ riyha ("cheirar") traduzida na interlinear hebraico-português ${ }^{68}$ como 'aspirar', e que também significa 'cheirar' ${ }^{69}$. O SENHOR não tem prazer, ou não se agrada, seria melhor traduzido como "eu não cheirarei as vossas assembleias festivas". O olfato é um dos sentidos essenciais do homem e, portanto, característica do Deus de Israel $(G n$ 8,21), mas não dos ídolos (Dt 4,28; SI 115,6). Sendo o sentido menos material, é um meio apropriado para a interação de Deus com o culto; pois Deus, ao cheirar o sacrifício, demonstra sua aceitação (1Sm 26,19). Em Amós 5,21 Deus se recusa a 'cheirar', 'não se deleita' nas assembleias solenes dos israelitas, o que indica que a injustiça anula as provisões do sistema sacrificial de Israel (cf. Lv 26,31) ${ }^{70}$.

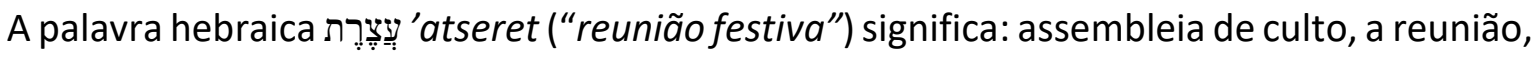
congregação do povo para adorar ao SENHOR (Dt 16,8; Lv 23,36; Nm 29,35; Is 1,3). O problema não está na forma de oferecer o sacrifício, mas na formalidade de um sacrifício externo, que está desconectado com a lei social e moral ${ }^{71}$.

'Tira de cima de mim' não seria uma tradução nem um pouco elegante, mas é o sentido expresso pelo hebraico, o sentido hifil do verbo no hebraico סוֹ our ("afastar") denota uma ordem enfática, de fazer desviar. Além de estar no hifil, o verbo o sur ("afastar") está no imperativo,

64 SCHWANTES, 2004, p.90-96.

65 PETERLEVITZ, Luciano R. Amós: o profeta, o contexto e o texto. Revista Theos - Revista de Reflexão Teológica da Faculdade Teológica Batista de Campinas. Campinas: 7ạ Edição, V.6 - № 01 - Julho de 2011, p.1.

66 A BíBLIA SAGRADA: Antigo e Novo Testamento. Tradução de João Ferreira de Almeida, Revista e Corrigida. 2. ed. São Paulo, SP: Sociedade Bíblica do Brasil, 2002.

67 A BÍBLIA SAGRADA, 2011, p.1621.

68 FRANCISCO, 2017, p. 596-597.

69 JENSON, P., \& OLIVIER, J. P. J., \& VANGEMEREN, W. A. (Org.). Novo Dicionário Internacional de Teologia e Exegese do Antigo Testamento, $1^{\text {a }}$ edição, Vol. 3, São Paulo, SP: Editora Cultura Cristã, 2011.

70 JENSON et al, 2011.

71 CRABTREE, 1960, p. 123.

Protestantismo em Revista | São Leopoldo | v. 45, n. 02 | p. 49-63| Jul./dez. 2019

Disponível em: <http://periodicos.est.edu.br/index.php/nepp> 
reforçando ainda mais a ordem enfática do hifil, tamanha era a rejeição por parte de Yahweh ao culto. Não atentarei ou escutarei enfatiza o repúdio de Yahweh pelo sistema cúltico, com sacrifícios, músicas e festividades, nos quais o SENHOR não teria comunhão com eles, e muito menos o aceitaria, no sentido de se tornar igual a eles, por não receber a obediência perfeita ${ }^{72}$.

Deus está enojado do fumo dos sacrifícios, está estonteado pelos sons e cantos dos seus fiéis, dando um basta para o culto formalista, vazio de sentido religioso verdadeiro ${ }^{73}$. Para Deus, o culto é vosso, o sacrifício é vosso e não meu $^{74}$. As reuniões, banquetes e a música se realizam para a própria satisfação do povo e não de Deus ${ }^{75}$. Não existe separação para Amós entre as práticas cúlticas festivas e o culto interior do coração, sendo que Deus não está confinado a um santuário ou práticas ritualistas, porque o que importa para adorar a Deus são a maneira e as disposições interiores ${ }^{76}$. Wolff ${ }^{77}$ afirma: "A crítica do serviço divino e o protesto contra a vida social de sua época se acham, em Amós, firmemente associadas".

O povo que oprimia se fundamentava nos santuários e na prática ritualista do culto para procurar em Deus proteção para a nação, prosperidade econômica, bem-estar material e saúde. Sendo que Deus havia sido transformado por este mesmo povo apenas em um 'meio' para conseguir o que desejava. Deus não pode e não deve ser o meio, mas o fim, a razão! O culto verdadeiro não pode ser uma instrumentalização, um 'uso' de Deus ${ }^{78}$.

A salvação de Yahweh para o culto, Am 5,24

\section{4}

24 E que o direito flua como as águas; e a justiça como manancial corrente.

A salvação oferecida por Deus através do profeta para o culto não são: reuniões festivas, sacrifícios, ofertas, nem cantos, nem sons, mas simplesmente: o direito e a justiça ${ }^{79}$ ! Os israelitas deveriam abandonar as ideias pagãs de comprar o favor divino através do culto, tentando subornálo, se estavam desconectados com a prática cúltica na vida diária ao não praticarem a retidão e a justiça. Uma justiça moral e ética é revelada pelas palavras do hebraico: טְִ̣̣ mishepat ("direito") e צִ tsedaqah ("justiça"). Mishepat é a palavra hebraica para direito, que é a prática da justiça na vida diária, nos negócios, na política e nas questões jurídicas ${ }^{80}$. Tsedaqah é a virtude do justo comportamental que edifica a comunidade em todos os seus aspectos: sociais, econômicos, políticos e religiosos ${ }^{81}$. É ser fiel à comunidade ${ }^{82}$. Uma justiça social, moral e ética diante dos homens e de Deus. As duas palavras juntas denotam a prática da justiça e que o povo se tornaria justo pela

72 CRABTREE, 1960, p. 123.

73 BONORA, 1988, p. 40.

74 JAMIESON, R., FAUSSET, A. R., \& BROWN, D.. Commentary Critical and Explanatory on the Whole Bible, Vol. 1, Oak Harbor, WA: Logos Research Systems, Inc, 1997, p. 675.

5 WOLFF, 1984, p. 41.

BONORA, 1988, p. 41.

WOLFF, 1984, p. 52.

BONORA, 1988, p. 41.

BONORA, 1988, p. 49.

BONORA, 1988, p. 49.

BONORA, 1988, p. 49.

82 JENNI, Ernst, \& WESTERMANN, Claus. Diccionario teologico manual del Antigo Testamento. v.1. Tradução de Rufino Godoy. Madrid, ES: Ediciones Cristiandad, 1978, p. 639.

Protestantismo em Revista | São Leopoldo | v. 45, n. 02 | p. 49-63| Jul./dez. 2019

Disponível em: <http://periodicos.est.edu.br/index.php/nepp> 
comunhão íntima com Deus e sua fé nele ${ }^{83}$. Essa justiça deve ser constante, perene, não impetuosa, como um ribeiro suave, sendo uma fé vigorosa e constante ${ }^{84}$.

A adoração no culto é usada como uma forma de troca com Deus, referente aos mandamentos da aliança. E Deus usa de uma linguagem forte nos versículos 21-23 para demonstrar total rejeição ao culto ${ }^{85}$, como demonstra Brown et a $^{86}$ : "O profeta usa aqui um artifício literário conhecido como 'negação dialética', na qual um aspecto (aqui, adoração) é fortemente negado a fim de dar ênfase a outrem (aqui, justiça v.24)".

Um culto exterior é a denúncia de Amós, que afirma que a liturgia e a vida andam juntas porque saem do interior, se uma está errada a outra também estará ${ }^{87}$. Até aqui, dos v. 21-23, em nenhum momento Deus rejeita o culto por causa de uma impureza ritual, mas por não estar acompanhado de atos de justiça e retidão ${ }^{88}$. 0 direito e a justiça devem ser praticados como única forma de salvação para este culto ritualista exterior que Deus odeia e rejeita ${ }^{89}$ !

O caminho de Yahweh para a salvação do culto, Am 5,25-27

5

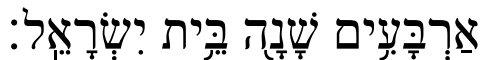

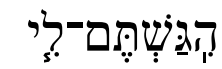

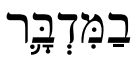

6
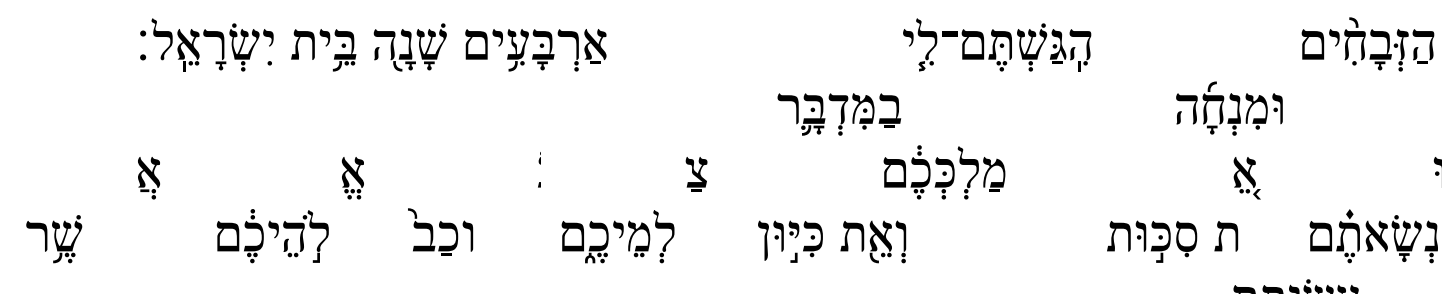

שֵֶׁר

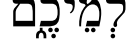

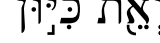

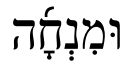

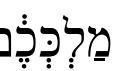

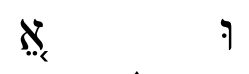

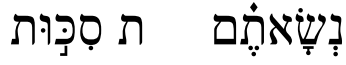

עִשֶׁיתֶם

\section{לרֶֶם}

7

פ :

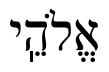

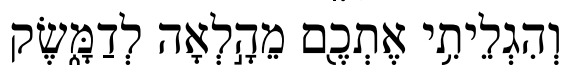

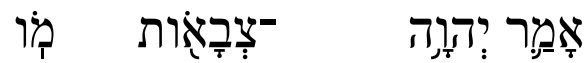

25 Por acaso sacrifícios e ofertas de cereais oferecestes-me no deserto, durante quarenta anos, ó casa de Israel?

26 E carregastes Sicut, o vosso rei, e Quium, as vossas imagens; a estrela dos vossos deuses fundiram/fizestes para vós.

27 (Eu) vos exilarei para além de Damasco, disse Yahweh, Deus dos Exércitos é o seu nome.

O deserto é uma releitura deuteronomista do caminho para a salvação da prática cúltica que Deus rejeitou. Sim, o direito e a justiça têm que fluir, mas para isso é necessário o deserto para a purificação! É a forma, o caminho de Deus até a salvação! No deserto, o povo passou por diversas adversidades. O fim do deserto seria uma terra que emana leite e mel, a terra prometida. Mas teriam que atravessar o deserto enfrentando: fome, sede, peste, cobras abrasadoras, tentações e provações da fé, para humilharem-se diante de Deus. Eles seriam aceitos, se obedecessem. No tema do deserto em Amós, os quarenta anos são o tempo ideal ${ }^{90}$.

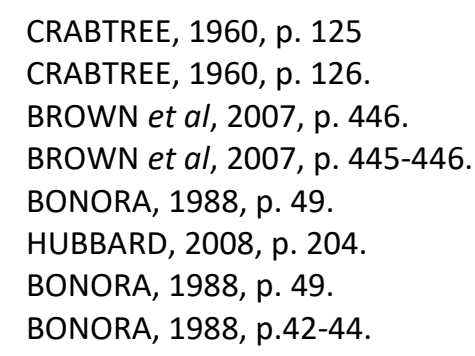

Protestantismo em Revista | São Leopoldo | v. 45, n. 02 | p. 49-63| Jul./dez. 2019 
No Êxodo do povo de Israel do Egito para Canaã, no qual passaram cerca de quarenta anos no deserto, como o sistema elaborado de sacrifícios ainda não existia, é mencionado uma única vez o sacrifício da Páscoa em Números 9, $5^{91}$. No deserto não havia sacerdotes instituídos, nem templo ou santuários, nem uma organização de culto, ou qualquer religião institucionalizada ${ }^{92}$. Talvez Israel tenha oferecido o sacrifício no deserto essa única vez, porque por mais que haja a ratificação das instruções acerca de sacrifícios, e essa homologada no Sinai (Êx 24,1-8), praticamente não há relatos a respeito da prática de sacrifícios no deserto ${ }^{93}$. Mas, mesmo assim, Yahweh cuidou deles no deserto com amor, porque na verdade a oferta tem valor secundário na prática cúltica, pois o verdadeiro culto começa no coração e é refletido na prática comum de justiça social e adoração única a Deus ${ }^{94}$.

O castigo e a sua qualidade, são anunciados pelo profeta: os israelitas serão exilados da sua terra, como sabemos que aconteceu com a queda de Samaria em 722 a.C. Sicute e Quium são deuses da Assíria, a qual o profeta Amós está afirmando que os estava adorando neste momento. Os israelitas haviam se contaminado com a culto dos cananeus e das nações vizinhas ${ }^{95}$. Essa grave infidelidade, essa adoração às imagens de outros deuses, somada à prática da injustiça, só poderiam resultar no mais severo castigo: na deportação de Israel, que levará consigo as suas imagens para o exílio. O SENHOR dos Exércitos, esse é o seu nome, coloca um contraste com os deuses da Síria, que nada podem fazer diante do SENHOR, dos poderes dos céus e da terra, e é isso que revela no fim do texto em hebraico ${ }^{96}$.

\section{Considerações finais}

De acordo com Balancin e Storniolo97: "o cerne de todas as críticas de Amós pode ser resumido em um só ponto: a perversão de uma religião, que em sua origem é essencialmente libertadora, para transformá-la em objeto de opressão". No tempo de Amós, todos os templos ou santuários haviam sido feitos em sistema de apoio à política opressora e para a economia que oprimia o povo. E ainda assim, pensavam de forma fatalista, que 'Deus queria assim', 'Que isso era vontade de Deus' quando surgiu Amós profetizando contra isso, demonstrando essa desordem, essa injustiça, que 'Deus não queria assim'. E dessa forma, ele trazia esperança à população explorada ${ }^{98}$.

O profeta assume a posição de defensor. Ele defende somente aquele a quem ninguém defende, assume a causa do oprimido, faz opção de ficar do lado do vulnerável. Ele sofre todas as afrontas perante a sociedade detentora do poder, mas não desiste e segue em seus gritos por justiça. Informa com veemência a situação dos detentores do poder político, econômico e religioso. Mostra suas faltas e pecados diante da comunidade que necessita de amparo e daqueles que nada fazem, ou seja, não cumprem o verdadeiro papel para o

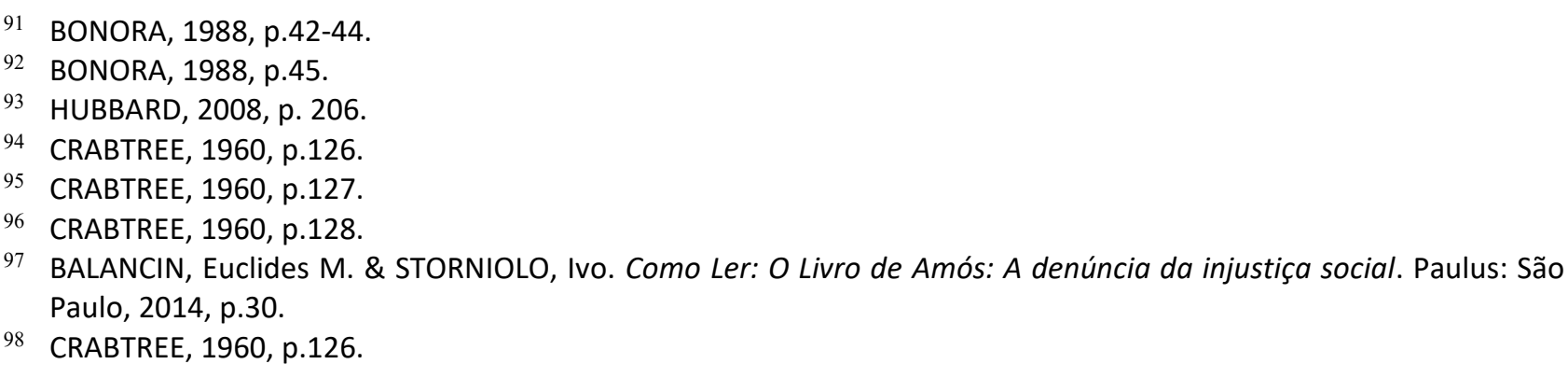

Protestantismo em Revista | São Leopoldo | v. 45, n. 02 | p. 49-63| Jul./dez. 2019

Disponível em: <http://periodicos.est.edu.br/index.php/nepp> 
qual foram designados, ou seja, de defesa e promoção de uma vida melhor para a sua comunidade. ${ }^{99}$

Mas, no meio da advertência do profeta Amós, a salvação pode fluir se o povo andar diariamente na prática do direito e da justiça, para que Yahweh aceite os seus cultos.

Corra como água o direito!

A justiça como ribeiro perene!

Amós contrapõe essa reivindicação às festas e aos ritos sacerdotais. Segui-la significaria a vida, certamente também para a gente do templo. ${ }^{100}$

A falsa adoração no culto a Deus o reduz à passividade, porque na adoração divina correta o homem experimenta a ação vivificadora de Deus. Em contraposição com a falsa adoração no culto que leva à vida profana. A adoração divina correta ativa uma vida comunitária diária da prática do direito e da justiça ${ }^{101}$. Hubbard afirma ${ }^{102}$ : "O interesse pelos direitos e pelo bem-estar de todo o povo de Deus flui como um rio caudaloso de seu próprio coração. Quem realmente quiser servi-lo deve acompanhar esse fluxo".

O caminho para se encontrar a salvação é o deserto: sem rituais, sem sacerdócio, sem ostentação, somente confiando em Deus dia após dia, levando o povo à humilhação, e possibilitando sua obediência pela fé e aceitação da salvação de Yahweh. Isso talvez tenha sido simbolizado pelo exílio, que revelou que aquele sistema social operante não tinha salvação, pois essa só poderia ser encontrada através da purificação e humilhação do indivíduo. "O culto comunitário é o resultado da ação pessoal de cada indivíduo da comunidade, por isso é tão necessário à mudança interna individual para uma prática ritualística do mesmo, a qual seja aceita por Yahweh, e que retome uma nova ordem social também aceita por Ele, dessa forma literalmente apreciada pelo cheiro dos sacrifícios que são aceitos pelo SENHOR.

\section{Referências}

A BíBlIA SAGRADA: Antigo e Novo Testamento. Tradução de João Ferreira de Almeida, Revista e Corrigida. 2. ed. São Paulo, SP: Sociedade Bíblica do Brasil, 2002.

A BíBLIA SAGRADA. A Bíblia de Jerusalém. Nova Edição Revista e Ampliada. 7ạ Impressão, edição de 1998, Editora Paulus: São Paulo, SP, 2011.

ALONSO SCHÖKEL, L., \& SICRE DIAZ, J.L. Profetas II: Introducciones y comentario: Ezequiel, Doce Profetas Menores, Daniel, Baruc, Carta de Jeremias. Com a colaboração de S. Breton e E. Zurro, Cristianad: Madrid, 1980. Disponível em <https://pt.scribd.com/document/340608932/Profetas-2Luis-Alonso-Schokel>. Acessado em 2 de outubro de 2018.

BALANCIN, Euclides M. \& STORNIOLO, Ivo. Como Ler: O Livro de Amós: A denúncia da injustiça social. Paulus: São Paulo, 2014, 40pp.

99 ROSSI, Luiz Alexandre Solano, \& ERDOS, Ivanilza Belmiro. O discurso profético de Miquéias em meio à violência e opressão e sua relevância para a atualidade. Estudos de Religião, v. 27, n. 2, p. 94-113, jul.-dez. 2013, p.95-96. Disponível em <https://www.metodista.br/revistas/revistas-ims/index.php/ER/article/download/3634/3758>. Acessado em 2 de outubro de 2018.

100 SCHWANTES, 2004, p. 79.

101 WOLFF, 1984, p. 54.

102 HUBBARD, 2008, p. 206.

Protestantismo em Revista | São Leopoldo | v. 45, n. 02 | p. 49-63| Jul./dez. 2019

Disponível em: <http://periodicos.est.edu.br/index.php/nepp> 
BONORA, Antônio. Amós, o profeta da justiça. Tradução de Pier Luigi Cabra. 2. ed. São Paulo: Paulinas, 1988.

BOSMAN, H. L. \& VanGemeren, W. A. (Org.). Novo Dicionário Internacional de Teologia e Exegese do Antigo Testamento. $1^{\text {a }}$ edição, Vol. 3. São Paulo, SP: Editora Cultura Cristã, 2011.

BROWN, Raymond E.; fitzmyer, Joseph A.; MURPHY, Roland E. Novo Comentário Bíblico São Jerônimo: Antigo Testamento. Trad. Celso Eronides Fernandes. São Paulo: Ed. Academia Cristã Ltda; Paulus, 2007.

CRABTREE, A.R. O Livro de Amós. Casa Publicadora Batista: Rio de Janeiro, 1960.

ELS, P. J. J. S., W. A. VanGemeren (Org.). Novo Dicionário Internacional de Teologia e Exegese do Antigo Testamento. $1^{\text {a }}$ edição, Vol. 3, São Paulo, SP: Editora Cultura Cristã, 2011.

FRANCISCO, Edson de Faria. Profetas Posteriores: Antigo Testamento Interlinear Hebraico Português. Volume 3. Sociedade Bíblica do Brasil: Barueri, SP, 2017.

HARRIS, Laird E. et al. Dicionário Internacional de Teologia do Antigo Testamento. Tradução Márcio Loureiro Redondo, Luiz Alberto T. Sayão, Carlos Osvaldo C. Pinto, Vida Nova: São Paulo, SP, 1998.

HUBBARD, David Allan. Joel e Amós: introdução e comentário. Tradução de Marcio L. Redondo. São Paulo: Edições Vida Nova, 2008. 274 p.

JAMIESON, R., Fausset, A. R., \& Brown, D. Commentary Critical and Explanatory on the Whole Bible. Vol. 1, Oak Harbor, WA: Logos Research Systems, Inc, 1997.

JENNI, Ernst \& WESTERMANN, Claus. Diccionario teologico manual del Antigo Testamento. v.1. Tradução de Rufino Godoy. Madrid, ES: Ediciones Cristiandad, 1978, p.639.

JENSON, P., \& Olivier, J. P. J., \& VanGemeren, W. A. (Org.). Novo Dicionário Internacional de Teologia e Exegese do Antigo Testamento. $1^{\text {a }}$ edição, Vol. 3, São Paulo, SP: Editora Cultura Cristã, 2011.

KIRST, Nelson et al. Dicionário Hebraico-Português \& Aramaico-Português. 21ạ Edição, Editora Sinodal: São Leopoldo, RS, Editora Vozes: Petrópolis, RJ, 2008.

KIRST, Nelson. Amós: textos selecionados. São Leopoldo: Faculdade de Teol.Igr. Evang.Conf. Lut., 3 V., Exegese, 1. 1981.

LOPES, Hernandes Dias. Amós: um clamor pela justiça social. São Paulo: Hagnos, 2008.

PETERLEVITZ, Luciano R. Amós: o profeta, o contexto e o texto. Revista Theos - Revista de Reflexão Teológica da Faculdade Teológica Batista de Campinas. Campinas: 7ạ Edição, V.6 - № 01 - Julho de 2011. Disponível em <https://pt.scribd.com/document/349095840/Artigo-07-01-05-AMOS-pdf>. Acessado em 19 de setembro de 2018.

REIMER, Haroldo. A Festa dos Pândegos Sobre o comer e beber no livro de Amós. Estudos Teológicos, v. 49 , n. 2, p. 344-355, São Leopoldo, jul./dez. 2009. Disponível em <http://periodicos.est.edu.br/index.php/estudos_teologicos/article/view/92/86>. Acessado em 3 de outubro de 2018.

RENDTORFF, Rolf. Antigo Testamento: uma introdução. Tradução de Monika Ottermann. Santo André, SP: Academia Cristã, 2009. 505 p.

ROSS, Allen P. Gramática do Hebraico Bíblico. Tradução Gordon Chown, 2 ed., Vida: São Paulo, 2008. ROSSI, Luiz Alexandre Solano, \& Erdos, Ivanilza Belmiro. O discurso profético de Miquéias em meio à violência e opressão e sua relevância para a atualidade. Estudos de Religião, v. 27, n. 2, p. 94-113,

Protestantismo em Revista | São Leopoldo | v. 45, n. 02 | p. 49-63| Jul./dez. 2019

Disponível em: <http://periodicos.est.edu.br/index.php/nepp> 
jul.-dez. 2013. Disponível em <https://www.metodista.br/revistas/revistasims/index.php/ER/article/download/3634/3758>. Acessado em 2 de outubro de 2018.

SCHMIDT, Werner H. Introdução ao Antigo Testamento. Tradução de Annemarie Hõhn I. 3a Edição. São Leopoldo, RS: Sinodal, 2004. 395p.

SCHÖKEL, Luís Alonso. Dicionário Bíblico Hebraico-Português. tradução Ivo Storniolo, José Bortolini. Editora Paulus: São Paulo, SP, 1997.

SCHWANTES, Milton. A terra não pode suportar suas palavras: reflexão e estudo sobre Amós. São Paulo: Paulinas, 2004.

SCHWANTES, Milton. Amós: Meditações e estudos. Sindoval: São Leopoldo, RS. 1987.

SMITH, G. V. Amós. Tradutores S. Klassen \& V. da S. Santos, $1^{\text {a }}$ edição, São Paulo, SP; Cambuci, SP: Editora Cultura Cristã, 2008.

WEIL, G. E., Elliger, K., \& Rudolph, W. Biblia Hebraica Stuttgartensia, SESB version, electronic ed., Stuttgart: German Bible Society, 2003.

WEIL, G. E., ELLIGER, K., \& RUDOLPH, W., Deutsche Bibelgesellschaft. Biblia Hebraica Stuttgartensia, 5. Aufl., rev., Stuttgart: Deutsche Bibelgesellschaft, 1997.

WOLFF, Hans Walter. Joel and Amos: a comentary on the books of the prophets Joel and Amos. Tradução de Waldemar Janzen; Edição de S. Dean McBride. 3. ed. Philadelphia: Fortress Press, 1989. WOLFF, Hans Walter. La hora de Amos. Tradução de Faustino Martinez Goñi. Salamanca: Sigueme, 1984. 